\title{
Quality Management of Vocational Skill Identification for Higher Vocational Education
}

\author{
Ping $\mathrm{Hu}^{1}$, Yumin $\mathrm{He}^{2, *}$ and Liying $\mathrm{Yu}^{1}$ \\ ${ }^{1}$ Shenyang Liming National Vocational Skill Identification Institute \\ ${ }^{2}$ Schools of Economics and Management, Beihang University \\ *Corresponding author. Email: heyumin@buaa.edu.cn
}

\begin{abstract}
The overall quality and skill level of workers also determines a country's competitiveness. It is important to improve quality for higher vocational education. This paper studies the quality management of vocational skill identification for higher vocational education. A case study is performed to study the quality management of a vocational skill identification institute. The research can provide a reference for similar institutes to improve quality in vocational skill identification for higher vocational education.
\end{abstract}

Keywords: Higher vocational education, Vocational skill identification, Vocational qualification, Quality management, Quality manual.

\section{INTRODUCTION}

The core of competition in the 21 st century is technology and talents. The overall quality and skill level of workers also determines the comprehensive competitive capability of a country. Quality is the foundation of vocational skill identification. It is required that higher vocational education should establish and improve the quality management system of vocational qualification, innovate in management to increase management level, adapt to the development of higher vocational education, and provide qualified high skill talents for enterprises.

Some higher vocational colleges and institutes in China still use the traditional way of vocational skill identification that can not meet the requirements of modern higher vocational education. Therefore, higher vocational colleges and institutes should establish and implement vocational qualification quality management system.

This paper studies the quality management of vocational skill identification for higher vocational education. A case study is performed to study the quality management of a vocational skill identification institute.

\section{QUALITY MANAGEMENT FOR HIGHER EDUCATION}

Higher education should also pay attention to quality management. Rezeanu [1] studied the implementation of quality management in higher education. He pointed out that adequate implementation of the total quality management was a methodology that can help teachers adapt to environment changes. He discussed three types of quality policies for higher educational systems.

Militaru et al. [2] pointed out the need for implementing total quality management (TQM) and described the characteristics of the implementation of TQM in higher education. These are optimization of faculty activities, vertical alignment, horizontal alignment, and a single command for all activities.

Todorut [3] emphasized the importance of total quality management. He described that TQM consisted three units that are core values, technique, and tools. $\mathrm{He}$ formed a TQM pyramid for higher education and discussed the quality of markets, the culture of quality in education, and the quality of education services for higher education.

Megnounif et al. [4] also discussed the need to improve the quality for higher education and pointed out the impact of the improvement not only affect students but also teachers, managers, employers, the institution, 
and all components of the system. They proposed an approach to improve the quality for higher education, which was based on 5 steps. These are collect data, establish needs, plan by objectives, implement quality system, and verify the implementation. They made a case study of the proposed quality approach to the faculty of Technology, University of Tlemcen. They made the steps of finding the needs, forming the plan, making the implementation and verification to support quality improvement.

\section{CASE STUDY}

A case study is made to a vocational skill identification institute. The institute has been the training base of mechanical and electrical projects for national high skilled talents, the experimental base of vocational training, and the experimental base of the national numerical control practice. The institute has offered the training of numerical control technology, mould design and manufacturing, mechanical and electrical equipment of aviation and its maintenance, mechanical manufacturing technology and equipment, mechanical manufacturing and automation, operation and maintenance of mechanical and electrical equipment, mechanical and electrical integration technology, and metal material and heat treatment technology. Among these, many professions are demonstrative ones provincially. The institute makes national vocational skill identification. Those who pass the identification can obtain the graded certificates of the national vocational qualification.

\subsection{Quality Management Policy and Objective}

The quality policies of quality management for vocational qualification in the institute are scientific and just, efficient management, customer first, and continuous improvement.

Quality objectives are identification accuracy ratio $100 \%$, customer satisfaction ratio $\geq 90 \%$, equipment intact ratio $\geq 95 \%$, identification complaints $\leq 3$ per year, and safety accidents 0 .

\subsection{Documented Quality Management File}

The construction of effective quality management system is one way to improve the quality of vocational skill identification. It can play an indispensable role in improving the quality and clarify the ideas of the quality control. The institute constructed documented quality management files based on the procedure of the vocational skill identification and the characteristics of the institute.

The function of system documents is to provide regulatory documents to guide the institute to carry out identification services and related quality activities. It provides guarantee for achieving the specified quality objectives and expected management objectives. It also provides the basis for continuous and effective evaluating and improving the system and process. The types of system documents include quality manual, procedure documents, and operation guidance documents.

\subsubsection{Quality Manual}

The quality manual is a document that provides the overall information of the quality management system to the internal and external of the institute and is also the programmatic document of the quality management system of the institute.

The quality manual includes the documented quality policies and quality objectives. It includes several parts.

The first part (Chapter 0-4) introduces the institute and explains the basis of the quality manual. It determines the general requirements, quality policies and objectives, document management control requirements and record management control requirements in the quality management system for vocational qualification.

The second part (Chapter 5) is the management responsibility and authority.

The third part (Chapter 6-7) is the realization of resource management and identification services.

The fourth part (Chapter 8-10) is the information management, measurement, analysis, improvement, and the use and management of the manual.

\subsubsection{Procedure Document}

Procedure documents are consistent information documents providing how to complete the activities of the quality management system. There are 14 procedure documents of the quality management system.

\subsubsection{Operation Guidance Document}

Operation guidance documents are specific provisions for the activities of the quality management system, including management standards, system, operation guidance, quality plans for specific services and projects, etc. It also includes standards and records required.

\subsection{Quality Management Implementation}

The implementation of the quality management system for the vocational qualification ran through the whole process of the vocational skill identification in the institute. In order to effectively implement the quality management system, the implementation 
followed the following principles: focusing on customers, playing leadership role, participation of whole staff, paying attention to process method and system approach, fact based decision-making, continuous improvement principle, and mutually beneficial relationship principle.

In addition, the quality management system of the institute carried out internal audit and management review. For some problems found in operation processes, the problems were corrected and preventive activities were put forward through information collection and analyses and through the identification of unqualified items.

\subsection{Evaluation}

After the implementation of vocational qualification quality management system, the institute carried out the customer satisfaction evaluation according to the customer-centred principle. 185 customer satisfaction questionnaires were distributed and 185 were recovered with the recovery rate of $100 \%$, including lathe workers, CNC lathe workers, milling workers, CNC milling workers, maintenance electricians, and others of 10 types.

Customer satisfaction survey includes seven items, according to the requirements of Shenyang Vocational Skill Identification Guidance Centre, combined with the suggestions of relevant experts. The proportions of the 7 items are examination organization arrangement $10 \%$, equipment and appraisal environment $10 \%$, examiner service attitude $20 \%$, examiner professional ability $10 \%$, efficiency of managers $20 \%$, fair and open appraisal $10 \%$, and examiner self-discipline $20 \%$. The customer satisfaction ratio is computed by Equation (1) for each level of satisfaction among very satisfied, satisfied, general, unsatisfied, very unsatisfied, where $\gamma_{i}$ is the proportion of item $\mathrm{i}, \mathrm{S}_{\mathrm{i}}$ is the data of a level for item $\mathrm{i}$.

$\mathrm{S}=\sum_{\mathrm{i}=1}^{\mathrm{n}}\left(\gamma_{\mathrm{i}} \times \mathrm{S}_{\mathrm{i}}\right)$

The effectiveness of the quality management system was analysed to evaluate the effectiveness of the implementing the system. The data of customer satisfaction was collected as before the implementation and after the implementation of the quality management system. The collected data before the implementation is in Table 1 and the collected data after the implementation is in Table 2.

Table 1. Customer satisfaction questionnaire (before system operation)

\begin{tabular}{|l|c|c|c|c|c|c|}
\hline \multicolumn{1}{|c|}{ Item } & $\mathrm{Y}_{\mathrm{i}}$ & $\begin{array}{c}\text { Very } \\
\text { Satisfied }\end{array}$ & Satisfied & General & Unsatisfied & $\begin{array}{c}\text { Very } \\
\text { Unsatisfied }\end{array}$ \\
\hline Examination organ. and arrang. & 0.1 & 165 & 8 & 12 & 0 & 0 \\
\hline Equipment and appraisal envir. & 0.1 & 174 & 6 & 5 & 0 & 0 \\
\hline Examiner service attitude & 0.2 & 169 & 10 & 6 & 0 & 0 \\
\hline Examiner professional ability & 0.1 & 159 & 11 & 15 & 0 & 0 \\
\hline Management efficiency & 0.2 & 161 & 9 & 15 & 0 & 0 \\
\hline Fair and open appraisal & 0.1 & 181 & 4 & 0 & 0 & 0 \\
\hline Examiner self-discipline & 0.2 & 180 & 5 & 0 & 0 & 0 \\
\hline Score & & 169.90 & 7.70 & 7.40 & 0.00 & 0.00 \\
\hline
\end{tabular}

Table 2. Customer satisfaction questionnaire (after system operation)

\begin{tabular}{|l|c|c|c|c|c|c|}
\hline \multicolumn{1}{|c|}{ Item } & $\mathrm{V}_{\mathrm{i}}$ & $\begin{array}{c}\text { Very } \\
\text { Satisfied }\end{array}$ & Satisfied & General & Unsatisfied & $\begin{array}{c}\text { Very } \\
\text { Unsatisfied }\end{array}$ \\
\hline Examination organ. and arrang. & 0.1 & 182 & 3 & 0 & 0 & 0 \\
\hline Equipment and appraisal envir. & 0.1 & 180 & 5 & 0 & 0 & 0 \\
\hline Examiner service attitude & 0.2 & 185 & 0 & 0 & 0 & 0 \\
\hline Examiner professional ability & 0.1 & 181 & 4 & 0 & 0 & 0 \\
\hline Management efficiency & 0.2 & 181 & 3 & 0 & 0 & 0 \\
\hline Fair and open appraisal & 0.1 & 185 & 0 & 0 & 0 & 0 \\
\hline Examiner self-discipline & 0.2 & 185 & 0 & 0 & 0 & 0 \\
\hline Score & & 183.00 & 1.80 & 0.00 & 0.00 & 0.00 \\
\hline
\end{tabular}


Table 1 shows that the value of the 7 items before the implementation of the quality management system for very satisfied is 169.9 . Table 2 shows that the value of the 7 items after the implementation of the quality management system for very satisfied is 183.0.

It can be computed that the improvement after the implementation is $7.7 \%$ in comparison to that before the implementation. Therefore, the customer satisfaction level after the implementation of the quality management system is increased. This indicates the improvement of quality level of the vocational skill identification and the suitability and effectiveness of the quality management system of vocational qualification of the institute.

\section{CONCLUSION}

It is also important to improve the quality for higher vocational education. This paper studies the quality management of vocational skill identification for higher vocational education. A case study is performed to study the quality management of a vocational skill identification institute.

The quality management system is developed in the institute. The documented quality management files are constructed based on the quality management policies and objectives. The quality management system is implemented and evaluated with the improvement of the implemented system. The research can provide a reference for similar institutes to improve quality in vocational skill identification for higher vocational education.

\section{ACKNOWLEDGMENTS}

The authors would like to thank the people who worked on the development and implementation of the quality management system.

\section{REFERENCES}

[1] O.M. Rezeanu. The implementation of quality management in higher education. Procedia Social and Behavioral Sciences vol. 15, 2011, pp. 10461050.

DOI:

https://doi:10.1016/j.sbspro.2011.03.237

[2] M. Militaru, G. Ungureanu, A.S. Chenic. The prospects of implementing the principles of Total Quality Management (TQM) in education. Procedia Social and Behavioral Sciences vol. 93, 2013, pp. 1138-1141.DOI: https:// doi:10.1016/j.sbspro.2013.10.003

[3] A.V. Todorut. The need of Total Quality Management in higher education. Procedia Social and Behavioral Sciences vol. 83, 2013, pp. 11051110.DOI: https:// doi:10.1016/j.sbspro.2013.06.207

[4] A. Megnounif, A. Kherbouche, N. Chermitti. Contribution to the quality assessment in higher education: the case study of the faculty of technology, Tlemcen, Algeria. Procedia Social and Behavioral Sciences vol. 102, 2013, pp. 276287.DOI: https:// doi:10.1016/j.sbspro.2013.10.742 